Volume 13

$12-20-2019$

\title{
Learning from High Risk Feminism: Emergent Lessons about Women's Agency in Conflict Contexts
}

Julia Margaret Zulver

University of Oxford

Follow this and additional works at: https://digitalcommons.usf.edu/gsp

\section{Recommended Citation}

Zulver, Julia Margaret (2019) "Learning from High Risk Feminism: Emergent Lessons about Women's Agency in Conflict Contexts," Genocide Studies and Prevention: An International Journal: Vol. 13: Iss. 3: 21-43.

DOI:

https://doi.org/10.5038/1911-9933.13.3.1670

Available at: https://digitalcommons.usf.edu/gsp/vol13/iss3/5

This Articles is brought to you for free and open access by the Open Access Journals at Digital Commons @ University of South Florida. It has been accepted for inclusion in Genocide Studies and Prevention: An International Journal by an authorized editor of Digital Commons @ University of South Florida. For more information, please contact digitalcommons@usf.edu. 


\section{Learning from High Risk Feminism: Emergent Lessons about Women's Agency in}

Conflict Contexts

\section{Acknowledgements}

The author wishes to thank Andrew Woolford, Alex Hinton, the participants at the Critical Genocide Prevention Workshop (University of Manitoba, October 2018), and the two anonymous reviewers for their insightful comments and suggestions. She also wishes to thank Roxani Krystalli for her thoughtful insights. 


\title{
Learning from High Risk Feminism: Emergent Lessons about Women's Agency in Conflict Contexts
}

\author{
Julia Margaret Zulver \\ University of Oxford \\ Oxford, United Kingdom
}

If preventative visits and fact-finding missions to areas of potential conflict were to routinely include gender expertise and consultation with women's organizations, systematic and useable information could be collected and analyzed. Only then could "gender perspectives" be turned into concrete early warning indicators... ${ }^{1}$

"What can we do in the context of a peace deal that is neither lasting nor stable?" asks a leader of a women's organization based in northern Colombia in an interview in August 2018, "Where is the justice?"2 This narrative is not uncommon among members of women's organizations (and indeed non-gendered social movements) in so-called post-conflict Colombia. ${ }^{3}$ Despite the formal cessation of hostilities with the FARC, ${ }^{4}$ violence continues between criminal groups, other armed rebel groups, dissident FARC members, international drug cartels, and even the armed forces. ${ }^{5}$ This violence has direct and targeted impacts on those who mobilize for peace and safety in their communities; in 2017, the UN High Commissioner for Human Rights registered 441 attacks and 121 murders of social leaders, including human rights defenders and social and community leaders. ${ }^{6}$ The interviewee above belongs to a women's organization that has received both collective and individual threats in recent months; one leader is being followed, others have received threatening pamphlets sent via messaging applications, still others have received phone calls telling them to stop their community activism.

The interviewee's question above went unanswered during the interview, but her meaning was clear: we will continue to fight, to struggle. Practically, this means that despite the threats, she and her compañeras will continue to: (1) fortify a shared identity as displaced women of the conflict, (2) strengthen community ties (bonding and bridging social capital), (3) creatively present the validity of their justice claims to various institutions (legal framing techniques), and (4) highlight their grievances through public protests (acts of certification). These are the actions that she and her organization have implemented in varying contexts of conflict and violence since they began in 1998. ${ }^{7}$ Indeed, these four strategies are the component parts of High Risk Feminism, a framework

${ }^{1}$ Felicity Hill, "Women's Contribution to Conflict Prevention and Early Warning and Disarmament," Women, Men, Peace, and Security 4 (2003), 17- 24, accessed November 9, 2019, https://www.unidir.org/files/publications/pdfs/women-menpeace-and-security-en-565.pdf.

${ }^{2}$ Here, the interviewee is referring to the formal title of the Peace Accords (Acuerdo Final para la Terminación del Conflicto y la Construcción de una Paz Estable y Duradera, Final Agreement for the Termination of the Conflict and the Construction of a Stable and Lasting Peace).

${ }^{3}$ For a counter-narrative on how mass atrocities end, see Alex de Waal, Jens Meierhenrich, and Bridget Conley-Zilkic, "How Mass Atrocities End: An Evidence-Based Counter-Narrative," The Fletcher Forum of World Affairs 36, no. 1 (2012), 15-31. For feminist work on conflicts and endings, see: Fionnuala Ní Aoláin, Dina Francesca Haynes, and Naomi Cahn, On the Frontlines: Gender, War, and the Post-Conflict Process (Oxford: Oxford University Press, 2011); Cynthia Cockburn, "Sexual Violence in Bosnia: How War Lives on in Everyday Life," OpenDemocracy, November 28, 2013, accessed November 21, 2019, www.opendemocracy.net/en/5050/sexual-violence-in-bosnia-how-war-lives-on-ineveryday-life/; Marie E. Berry and Trisha R. Rana, "What Prevents Peace? Women and Peacebuilding in Bosnia and Nepal," Peace and Change 44, no. 3 (2019), 321-349.

${ }^{4}$ Fuerzas Armadas Revolucionarias de Colombia (FARC), the Revolutionary Armed Forces of Colombia, a Marxist-Leninist rebel group that was at war with the Colombian government for 52 years, until a peace deal was reached in 2016.

${ }^{5}$ Magali Alba et al., "Challenges in Colombia's Changing Security Landscape: Toward a Shared Vision of Peace," LASA Forum 49, no. 3 (2018), 75-80. See also, Nicholas Casey, "Colombia Army's New Kill Orders Send Chill Down Ranks," New York Times, May 18, 2019, accessed November 21, 2019, www.nytimes.com/2019/05/18/world/americas/colombianarmy-killings.html.

${ }^{6}$ United Nations Office of the High Commissioner for Human Rights, Informe Anual Del Alto Comisionado de Las Naciones Unidas Para Los Derechos Humanos Sobre La Situación de Los Derechos Humanos En Colombia, March 21, 2018 (UN Doc. A/ $\mathrm{HRC} / 34 / 3)$.

${ }^{7}$ Julia Zulver, "Building the City of Women: Creating a Site of Feminist Resistance in a Conflict Zone," Gender, Place, and Culture 24, no. 10 (2017), 1498-1516. 
designed to showcase the "various forms of agency that women adopt, create, modify, and employ to counteract fragility in their daily lives."

I developed the concept of High Risk Feminism (hereafter, HRF) in previous research based in Colombia and El Salvador to allow scholars to understand women's mobilization in contexts of what Sandvik frames as the "gender of violent pluralism." ${ }^{9}$ As will be discussed below, she highlights the need to: "make sense of women political activists as survivors and actors, where experiences of violence and loss shape strategies and tactics in the present." ${ }^{10}$ Indeed, when it comes to studies about conflict and violence, much of the literature about women still resorts to a narrative that paints women as victims. Within studies of transitional justice, Baines points to and then challenges the line of thinking in which "the 'ideal victim'... is a person without agency, and the perpetrator, an individual whose unbounded agency must be disciplined and brought under control." ${ }^{\prime 11}$ If there is deviation from the victim narrative, women are framed in their maternal capacity as being able to take care of others and/or build and restore social fabric in communities in the aftermath of violence. While this may be an accurate assessment in many cases, it does not allow these women agency in terms of the strategies they employ to protect themselves and rebuild their lives, both in contexts of continuing violence, and also in the uncertain times of post-conflict eras.

Furthermore, when it comes to genocide and atrocity crime prevention research, this gendered essentialism continues. While scholars increasingly focus on the gendered elements of genocide, ${ }^{12}$ these are not often holistically discussed in the prevention literature. There is a tendency to fall into a gendered binary, whereby prevention is a masculine activity, while peacebuilding is represented as more maternal and feminine. ${ }^{13}$ This problematic division highlights a worrying pattern both in the literature and in practice. Indeed, even the UN Women, Peace and Security agenda has been accused of "[perpetuating] a protectionist narrative" by failing to better enable or support "women's participation in peace and security processes." 14 Dianne Otto goes one step further, arguing that the Security Council continues to rely on the "gendered paradigm that men fight wars in order to protect women (and children), and that women are naturally predisposed to peace."15

This article will challenge the trend of gendered essentialism and read genocide and atrocity crimes "from the bottom up", as suggested by Elisa von Joeden-Forgey (whose work is an exception

${ }^{8}$ Julia Zulver, “High-Risk Feminism in El Salvador: Women's Mobilisation in Violent Times," Gender and Development 24, no. 2 (2016), 172.

${ }^{9}$ Kristin Bergtora Sandvik, “Gendering Violent Pluralism: Women's Political Organising in Latin America," Third World Thematics: A TWQ Journal (2018), 12.

${ }^{10}$ Ibid.

${ }^{11}$ Erin Baines, “'Today, I Want to Speak Out the Truth': Victim Agency, Responsibility, and Transitional Justice," International Political Sociology 9, no. 4 (2015), 2.

${ }^{12}$ See, for example: Adam Jones, "Gender and Genocide in Rwanda," Journal of Genocide Research 4, no. 1 (2002), 65-94; Charli Carpenter, "Beyond 'Gendercide': Incorporating Gender into Comparative Genocide Studies," The International Journal of Human Rights 6, no. 4 (2002), 77-101; Laura Sjoberg, Women as Wartime Rapists: Beyond Sensation and Stereotyping (New York: New York University Press, 2016); Doris Buss, “The Curious Visibility of Wartime Rape: Gender and Ethnicity in International Criminal Law," Windsor Yearbook of Access to Justice 25, no. 1 (2007), 3-22.

${ }^{13}$ An idea often promoted through the use and misuse of Sara Ruddick's seminal text, Maternal Thinking. In the preface to the second edition of her book, she is careful to reiterate that she does not think that women or mothers are inherently "peaceful", but rather that their actions and efforts could be used as a resource for peace. See Sara Ruddick, Maternal Thinking: Towards a Politics of Peace, 2nd ed. (Boston: Beacon Press, 1995); Carol Cohn, "'Maternal Thinking' and the Concept of 'Vulnerability' in Security Paradigms, Policies, and Practices," Journal of International Political Theory 10, no. 1 (2013), 46-69.

${ }^{14}$ Anne Marie Goetz and Rob Jenkins, "Participation and Protection: Security Council Dynamics, Bureaucratic Politics, and the Evolution of the Women, Peace, and Security Agenda," in The Oxford Handbook of Gender and Conflict, ed. Fionnuala Ní Aoláin et al. (Oxford: Oxford University Press, 2018). See also: Paul Kirby and Laura J. Shepherd, "The Futures Past of the Women, Peace and Security Agenda," International Affairs 92, no. 2 (2016), 373-392; Pablo CastilloDiaz and Hanny Cueva-Beteta, "The Promise and Limits of Indicators of Women, Peace and Security," in The Oxford Handbook of Gender and Conflict, ed. Fionnuala Ní Aoláin et al. (Oxford: Oxford University Press, 2017).

${ }^{15}$ Dianne Otto, "Women, Peace, and Security: A Critical Analysis of the Security Council's Vision," in The Oxford Handbook of Gender and Conflict, ed. Fionnuala Ní Aoláin et al. (Oxford: Oxford University Press, 2018). 
to the above trend). She suggests: by including nuanced gender-sensitive research, we will better understand atrocity and thus inform early warning and prevention strategies. ${ }^{16}$

Even when gender is taken into account in genocide prevention research, there is something uncomfortable about how analysis instrumentalizes the reason women and their experiences should be taken into account. ${ }^{17}$ For example, Matveeva reflects on a report released by International Alert: "the rationale behind introducing gender into early warning rests upon the argument that the use of a gender-lens enriches early warning analysis and allows for more appropriate response options." 18 While at face value this is not necessarily problematic, she continues, it is based on three hypotheses that place women in "micro-level events" as opposed to "macro-level conflict" and that seek to hone in on the potential of "women... as actors for peace." ${ }^{19}$ Like Matveeva, I question if "the reality is...as straightforward." ${ }^{20}$ My contention is slightly different from hers, however: I question the implication that women's supposedly peaceful nature makes them well suited to onthe-ground prevention efforts.

To bring this conversation about agency and gender analysis back to critical genocide studies, we can turn to Alex Hinton, who tells us that "critical genocide studies takes place in the gutter," the space between frames, or the gap to be filled, ${ }^{21}$ and that we need to unpack and decenter the assumptions of the field. This can be read alongside the work of Oliver Kaplan, which unpacks assumptions regarding agency and civilian resistance in Colombia: "civilians are not necessarily passive or powerless. They are actors with agency whose ability to respond to dangers of conflict derives from social cooperation." 22 He continues, "social cohesion affords civilians greater chances to overcome fear, break 'laws of silence'... and implement collective strategies for protection." ${ }^{23}$

This article overlays a gendered lens on these assertions. It highlights that women do not always exclusively mobilize for others, nor do they fit neatly within circumscribed categories of victims, nor peacebuilders. Rather, they have the ability to develop and refine a contextually relevant style of feminist agency that allows them to navigate and make sense of the violences to which they are exposed, even during times of high risk. Given my own regional focus, the present article will largely focus on literature and case studies from Latin America. Despite this, the article will expand beyond case studies to draw out some of the emergent lessons about women's (particularly) feminist agency in conflict contexts more broadly. ${ }^{24}$ This article is not prescriptive but rather, descriptive; describing the ways in which women choose to protect themselves allows us important insight into local forms of protection, agency from below.

The article will proceed as follows: (1) it will examine the outdated ways in which women and conflict are studied and highlight why these are not universally applicable; (2) it will highlight lessons of HRF for genocide prevention; (3) and it will underscore the importance of recognizing and studying women's agency in conflict situations, with particular attention to the intersectional complexity of agency. It will then speak to how the lessons learned from HRF have the potential to

${ }^{17}$ To be clear, embracing a gendered approach to genocide prevention and analysis is not the same as engaging with women as actors. The former looks at power dynamics between gender, including masculinities, and how these influence genocide and atrocity crimes. This difference is well-documented in Carpenter, Beyond 'Gendercide'. It is further outlined by Kimberly Theidon, who critiques the trend whereby "'adding gender' is policy-speak for 'adding women'." Kimberly Theidon, "Reconstructing Masculinities: The Disarmament, Demobilization, and Reintegration of Former Combatants in Colombia," Human Rights Quarterly 31, no. 1 (2009), 4.

${ }^{18}$ Anna Matveeva, "Early Warning and Early Response: Conceptual and Empirical Dilemmas," Issue Paper 1 (The Hague: European Centre for Conflict Prevention, 2006).

${ }^{19}$ Ibid., 18.

${ }^{20}$ Ibid., 20.

${ }^{21}$ Alexander Hinton, "Afterword: Wonder Woman, the Gutter, and Critical Genocide Studies," in Memory and Genocide: On What Remains and the Possibility of Representation, ed. Fazil Moradi et al. (New York: Routledge, 2017), 167.

${ }^{22}$ Oliver Kaplan, Resisting War: How Communities Protect Themselves (Cambridge: Cambridge University Press, 2017$), 3$.

${ }^{23}$ Ibid., 9.

${ }^{24}$ Women's agency is not necessarily the same as feminist agency. Indeed, as Kreft notes, "women's organizations do not need to embrace an explicitly feminist platform in order to challenge... patriarchal culture, and the issues around which women mobilize, and the way in which these are articulated may differ." Anne-Kathrin Kreft, "Responding to Sexual Violence: Women's Mobilization in War," Journal of Peace Research 56, no. 2 (2019), 223. 
inform intervention and policy, particularly in terms of women's resilience and agency.

\section{Outdated Ways of Studying Women's Activism and Conflict:}

The literature is clear that women and girls suffer conflict and atrocity differentially. This is not news. ${ }^{25}$ Cockburn, for example, posits that war and conflict impact women differently than men, and that visions of security must also bear this in mind if lasting peace is to be secured. ${ }^{26}$ Boesten and Wilding note a "consensus in feminist literature about the continuum of gender based violence: the idea that violence against women may take different forms and be of a different scale during periods of conflicts." ${ }^{27}$ In the Colombian conflict, for example, there is literature that shows that massacres at Bahía Portete and El Salado and the paramilitary control of communities in Bajo Putumayo involved the murder and torture of women in order to destroy the communities' social fabric. ${ }^{28}$ Furthermore, there is growing research that also asks which women experience conflict differently from other women; this intersectional focus will be further discussed below.

In recent years, importantly, the literature has moved away from a black and white victimperpetrator binary. ${ }^{29}$ Despite this, there is still a tendency to instrumentalize the roles that women can and do play in conflict and post-conflict settings, even in the context of the Women, Peace and Security Agenda (discussed below). ${ }^{30}$ Scholars and practitioners might assess women in their capacities (i.e. their ability to protect their children), or their ability to be peacebuilders (i.e. their ability to re-weave social fabric). Sometimes, if women transgress these gender boundaries, we focus on them as revolutionaries or guerrillas. ${ }^{31}$

Before detailing some of the established ways that we think about and represent women who resist their violent surroundings to engage in some sort of collective action, it is first important to unpack the category of "women's organization" itself. For the purposes of this article, and my research in general, I speak about women's groups, women's organizations, or HRF organizations to refer to local, non-political, non-professional groupings of women. I use the word local (or grassroots) to differentiate these groups from national or regional, more professionalized projects (like Sisma Mujer or the Ruta Pacífica in Colombia). ${ }^{32}$ The constituent members came together in solidarity as a direct result of their conditions as survivors of the violence of the conflict; they also share an ongoing condition of vulnerability to further (and sometimes retributive) acts of violence. Below, I will discuss inter-group tensions and differences in order to highlight that despite creating collective identity to allow for grassroots resistance, the women who engage in HRF do not represent a homogenous bloc. Despite this: "a critical genocide studies might help us understand how a wide variety of identities, including non-Western ones, crystallize... in a variety of genocidal situations." 33

Mobilizing as Mothers:

In Latin America, the natural place to begin studying women who resist conflict is with the Madres de Plaza de Mayo, the heroic image of mothers in politics. ${ }^{34}$ During the military dictatorship in Argentina (1976-1983), a cross-class group of mothers engaged in peaceful protest to find their children who had been disappeared by the state. They marched around the statue at the Plaza de Mayo in Buenos Aires, calling on the military junta to give them information about their children. They did so despite the great personal risk this implied: the dictatorship was notoriously violent against anyone who dared dissent. Moreover, they had personal knowledge of the violence they risked because of what had happened to their children.

Navarro explains that the women were able to engage in collective action against the repressive state because they created a new political opportunity by mobilizing from their social location as

\footnotetext{
${ }^{32}$ For more on the tensions between professionalized feminist groups and grassroots women's organizations in Colombia, see Donna Murdock, When Women Have Wings: Feminism and Development in Medellin, Colombia (Ann Arbor: University of Michigan Press, 2008).

${ }^{33}$ Alexander Hinton, "Critical Genocide Studies," Genocide Studies and Prevention 7, no. 1 (2012), 9.

${ }^{34}$ Jane Jaquette, “Conclusion: Women's Political Participation and the Prospects for Democracy," in The Women's Movement in Latin America: Participation and Democracy, ed. Jane Jaquette (New York: Westview Press, 1994), $223-238$.
} 
mothers. ${ }^{35}$ That is, acting as mothers allowed the women to "achieve new identities and roles." 36 Elshtain, for example, theorizes about the transformations that these mothers underwent as $a$ function of their mobilization. ${ }^{37}$ She says that in fact, it was their mobilization - the act of coming together in the first place -that gave them the ability to manage their emotions and generate change through action. By talking about human rights, they were:

Afforded... a framework within which to canalize their grief - to make it do political work. And those Mothers who seemed to me to be coping best were those who had been able to transcend somewhat the vortex of personal devastation and make common cause, through human rights efforts, with their fellow Argentines and human rights activists internationally. ${ }^{38}$

More than just a "sorority bound by $\operatorname{loss}^{39}$ the Mothers became a force to be reckoned with, by using their disobedience to transform their roles as mothers (supposedly powerless and weak) into a strategic strength that could confront a brutal dictatorship.

It is clear that the Mothers perceived themselves as less likely to face repression than fathers, for example, would. Despite this, it is important to highlight that they did not think they were safe; they were keenly aware of what the regime was capable of doing because of their losses (their children). They knew that they had a certain cultural legitimacy to mobilize as mothers looking for their children but also recognized that the regime would not necessarily avoid repressing them, as was evidenced by the disappearance of three of the founders and the French nuns.

There are many parallels to be drawn between the case of the Madres in Argentina and the Madres de Soacha in a marginalized neighborhood of Bogotá, Colombia. This case refers to the mothers of sons who were part of the "false positive" scandal between 2002-2010. ${ }^{40}$ In seeking guarantees of truth, justice, reparation, and non-repetition for the disappearance, torture, and murder of their sons, these mothers developed a unique form of transformational political agency that they continue to express in their struggle against ongoing impunity and corruption. ${ }^{41}$ Moving beyond Latin America, parallel dynamics developed during Egypt's Arab Spring, where "women activists used their identities as mothers to negotiate with and contest the barriers to their participation presented by patriarchal elements of society and the state." 42

\section{Women as Peacebuilders}

This assumption of inherent maternal-ness further leads us to another stream of thinking: women as peacebuilders. To be clear, this article does not seek to negate the robust information that recognizes the unique role that women can play in post-conflict situations. Rather, it seeks to problematize the assumptions that are perhaps not always questioned when framing women in

\footnotetext{
${ }^{35}$ Marysa Navarro, “The Personal Is Political: Las Madres de Plaza de Mayo," in Power and Popular Protest: Latin American Social Movements, ed. Susan Eckstein (Berkeley: University of California Press, 1989), 241-259.

${ }^{36}$ Jaquette, Conclusion, 225.

${ }^{37}$ Jean Bethke Elshtain, “The Mothers of the Disappeared: An Encounter with Antigone's Daughters," in Finding a New Feminism: Rethinking the Woman Question for Liberal Democracy, ed. Pamela Grande Jensen (Lanham: Rowman \& Littlefield Publishers, Inc., 1996), 129-149.

${ }^{38}$ Ibid., 141.

${ }^{39}$ Elshtain, The Mothers of the Disappeared, 131.

${ }^{40}$ This was a phenomenon whereby innocent civilian boys and young men were killed and dressed up to look like rebel soldiers in order to inflate official figures of how many FARC soldiers had been killed by the army. Officers who carried out the executions were rewarded with promotions and time off. For more, see Joe Parkin Daniels, "Colombian Army Killed Thousands More Civilians than Reported, Study Claims," The Guardian, May 8, 2018, accessed November 21, 2019, https://www.theguardian.com/world/2018/may/08/colombia-false-positives-scandalcasualties-higher-thought-study; Omar Rojas and Fabián Benavides, Ejecuciones Extrajudiiales En Colombia, 2002-2010: Obediencia Ciega En Campos de Batalla Ficticios (Bogotá: Universidad Santo Tomás, 2017).

${ }^{41}$ Rocío Mateo Medina, “De Madres de Soacha a Sujetas Políticas: Capacidad de Agenia Ante La Impunidad En Colombia: Recontrucción de Un Caso Desde Una Mirada Feministas Para Un Litigio Estratégico," ICIP Working Papers 4 (2013), $1-57$.

${ }^{42}$ Anwar Mhajne and Crystal Whetstone, "The Use of Political Motherhood in Egypt's Arab Spring Uprising and Aftermath," International Feminist Journal of Politics 20, no. 1 (2018), 55.
} 
their unique ability to heal and rebuild communities. One clear example comes from the UNSC Resolution 1366 which notes that the Security Council:

Reiterates its recognition of the role of women in conflict prevention and requests the Secretary-General to give greater attention to gender perspectives in the implementation of peacekeeping and peace-building mandates as well as in conflict prevention efforts. ${ }^{43}$

Multiple international resolutions, including the 1995 Beijing Platform for the Action, UN Security Council Resolution 1325, and the nine subsequent "Women, Peace and Security" (WPS) resolutions passed by the UN Security Council, include commitments to promoting women's agency in conflict resolution and peacebuilding. ${ }^{44}$ These resolutions seek to: "involve women in conflict prevention, to protect them during and after conflicts, and to secure their full participation in post-conflict reconstruction." ${ }^{45}$ The UN Security Council has called on member countries to pay more attention to the role of women's leadership, to support women's engagement in decisionmaking, and to focus on women's empowerment in peacebuilding. Despite this, many barriers to peace in women's lives remain, as outlined by Berry and Rana who note that:

While formal peacebuilding interventions play an important role as scaffolding for grassroots peacebuilding work, these efforts will be insufficient insofar as they fail to center the informal, emotional, embodied, and creative ways that women pursue peace in their daily lives. ${ }^{46}$

Indeed, in her gendered continuum of violence, Moser articulates the idea that assessments of the impacts of violence on a country and its society's capital can provide insight into the true cost of violence. ${ }^{47}$ In situations of high levels of violence, she outlines that the relationship between violence and social capital is highly complex: "violence can erode productive social capital when it reduces trust and cooperation within formal and informal social organizations that are critical for a society to function." ${ }^{48}$ In communities where residents describe their lack of trust in terms of "lack of social fabric," ${ }^{49}$ women's groups have the potential to forge new networks that have the dual purpose of producing a private good (the benefits of support and kinship gained by individual membership) and a public good (rebuilding trust in state institutions, which may eventually serve to lessen structural violence that results, in the first place, in contexts of high violence).

Molyneux highlights that social capital ${ }^{50}$ has entered policy dates in a diverse network of fields, including development and community regeneration. She further notes that women frequently engage in collective survival strategies ${ }^{51}$ and that their efforts have "been essential in conflict and post-conflict situations where by working on common agendas, women have helped to heal deeply divided communities as well as to participate in the difficult task of post-conflict reconstruction." 52 In her chapter she highlights, however, that when women work together they still occupy gendered social spaces that are located within unequal power relations.

She discusses, for example, women's groups in Northern Ireland that became active in peace

${ }^{43}$ United Nations Security Council, Resolution 1366, August 31, 2001 (UN Doc. S/RES/1366).

${ }^{44}$ Anne Marie Goetz and Rob Jenkins, "Agency and Accountability: Promoting Women's Participation in Peacebuilding," Feminist Economics 22, no. 1 (2016), 216.

${ }^{45}$ Ibid.

${ }^{46}$ Berry and Rana, What Prevents Peace?

${ }^{47}$ Moser, Gendered Continuum of Violence, 41.

${ }^{48}$ Ibid., 44 .

${ }^{49}$ Ibid., 159.

50 "Commonly understood, following Putnam, as the social cement generated by associational life and by citizens' networks of trust and solidarity." Maxine Molyneux, "Women's Grass-Roots Organisations and Solidarity Networks: A Rediscovered Policy Resource," in Des Brèches Dans La Ville: Organisations Urbaines, Environement et Transformation Des Rapports de Genre, ed. Christine Verschuur and François Hainard (Bern: Graduate Institute Publications, 2016$), 1$.

${ }^{51}$ Ibid., 2.

${ }^{52}$ Ibid., 3 . 
movements out of concern for their families. Indeed, solidarity around domestic concerns "can be the basis for an informal citizenship that relocates women's domestic concerns and activities from the isolation of the family into public spaces and public life." 53 Women who originally mobilized around practical interests (including their family's needs) might go through a transformative process, which leads them to question and contest strategic interests (like gender inequality more broadly). ${ }^{54}$

Importantly, though, she discusses the problems that arise when policies begin to rely on women's organizations and their voluntary work (i.e. their ability to create social capital), including their instrumentalism (i.e. they become a substitute for appropriate government action). ${ }^{55}$ Secondly, she notes, grassroots organizations can be captured or co-opted by those looking to take advantage of women's participation for their own political gains. Thirdly, women can become overloaded by the kind or quantity of work that women are asked to do by NGOs or state-run programs. In these situations, the needs of the women themselves are not considered. ${ }^{56}$

What is instrumentalizing about this narrative is the perpetuation of the notion that women are inherently 'peaceful'. For example, Restrepo's study on Colombian women explores the ways in which some victims overcome their victimhood, emerging as leaders in peacebuilding, despite the significant risks associated with the ongoing violence..$^{57}$ It is not difficult to agree with her assessment that "against all odds, these unsung [women victim] leaders have proven to be powerful agents of change." ${ }^{\prime 58}$ What is not always the case, however, is her framing of women leaders as "capable of healing, empowering, and even reconciling broader society." 59 This echoes what Mwaûra and Schmeidl note about the Horn of Africa, where "early warning and preventative activities can be made more effective by using untapped potential for women (leaders), women's networks, and women's organizations as actors for peace." 60

To once more reiterate, in this article I do not wish to deny the real and positive outcomes that can result from including women in peace processes and peacebuilding efforts. Furthermore, I do not want to discount the measured and tangible outcomes that can result from women's unique ability to build social capital in both violent and post-conflict societies. Rather, I wish to echo Jacquette, who questions whether women can be "citizens if they always act in the interest of others." 61

Importantly, Sahla Aroussi presents a feminist critique of the stereotypical associations of women and peacefulness that are so often included in the literature, suggesting that these are mythical and linked to maternal ideologies and sociological and biological traits. ${ }^{62}$ Goetz and Jenkins further review the literature that demonstrates that a "pacifist/maternalist - as opposed to equality-based - justification for participation depoliticizes women's agency." ${ }^{63}$ These authors suggest that we tend to focus on women as nurturing peacebuilders (or mobilizing on behalf of others), and that this does not allow the necessary space to understand where women's agency fits within this narrative.

The HRF framework offers this space, allowing an analysis of the motivations with which women justify their mobilization. These are not necessarily related to the wider landscape of

\footnotetext{
${ }^{53}$ Ibid., 5 .

${ }^{54}$ Molyneux, Mobilisation without Emancipation?

${ }^{55}$ Molyneux, Women's Grass-Roots Organisations, 5. See also, Milli Lake, Strong NGOs and Weak States: Pursuing Gender Justice in the Democratic Republic of Congo and South Africa (Cambridge: Cambridge University Press, 2018).

${ }^{56}$ Ibid., 7.

${ }^{57}$ Elvira Maria Restrepo, “Leaders against All Odds: Women Victims of Conflict in Colombia," Palgrave Communications 2, no. 16014 (2016).

${ }^{58}$ Ibid., 1.

${ }^{59}$ Ibid.

${ }^{60}$ Cirû Mwaûra and Susanne Schmeidl, Early Warning and Conflict Management in the Horn of Africa (Asmara, Eritrea: The Red Sea Press, Inc., 2002), 89.

${ }^{61}$ Jaquette, Conclusion, 255.

${ }^{62}$ Sahla Aroussi, “Women, Peace and Security: Moving Beyond Feminist Pacifism,” (presentation, 2009), PSA Annual Conference.

${ }^{63}$ Goetz and Jenkins, Agency and Accountability, 215.
} 
healing society more broadly. It is important to see women's mobilization as an act of resistance to protect themselves, and not necessarily in the interest of others. While Restrepo aims to change the narrative of women as needy, helpless victims by painting them as potential peacebuilders, this article suggests that a further step can be taken; women can overcome victimhood and claim a feminist agency to resist the specific violences they face. This is a specifically feminist project, not necessarily predicated on the greater good of peacebuilding.

\section{New Focus: Emergent Lessons about High Risk Feminism:}

In her 2018 article, Sandvik offers an important critique on existing studies of violent pluralism (as included in Arias and Goldstein's concept of violent democracies). ${ }^{64}$ She notes that gender-neutral analyses fall short when explaining the ways in which violent pluralism impacts the relationships between political organizing and gendered violence. She suggests that gendered violence can be an obstacle to organizing, that women's political organizing can be a response to gendered violence, or that political organizing is a cause of further gender-based violence. ${ }^{65}$ This article focuses on the second assertion: mobilization as a response to violence. There are many ways in which women (for Sandvik, internally displaced women in the case of the Colombian conflict) engage in political organizing; this mobilization, she highlights, "should be scrutinized for what it can tell us about how collective feminist political subjectivities are construed through gender violence as a mobilizing factor." ${ }^{\prime 66}$ Anne-Kathrin Kreft's work adds to this discussion by theorizing that women mobilize in response to the collective threat that sexual violence during times of civil war poses to them as women, eventually leading to a situation where: "women mobilize in response to this violence and around a broader range of women's issues with the goal of transforming sociopolitical conditions." ${ }^{67}$

High Risk Feminism is a framework that emerged from my research in El Salvador and Colombia, which answered the questions: why and how do women mobilize in contexts of high violence and insecurity? These questions are predicated on the assumption that when violence is rife, and when acting collectively necessarily implies exposing oneself to even more violence, that women would choose to protect themselves by keeping a low profile. As the following sections will show, however, certain women in both El Salvador and Colombia are visible and present in the streets, making demands about gender justice more broadly. The "how" of the above-posed question can be answered using the HRF framework. In some situations, women living in highly violent contexts take to the streets, courts, institutions of the state, social networks, and neighborhoods. Their collective action takes the form of feminist resistance to gendered violence. In these situations (domains of losses), women organize their mobilization around four pillars: building collective identity, generating (bonding and bridging) social capital, employing legal framing, and engaging in acts of certification.

This article will now outline the main emergent lessons that we can take away from the HRF framework. These lessons have implications in terms of the way that we both study women in conflict settings, but also about the ways in which policies and interventions can best serve these marginalized populations. Finally, as these studies take place "in the gutter" - Hinton's space between frames - they serve to challenge the assumptions genocide and atrocity crime studies and prevention.

Women Do Mobilize in High Risk Settings

The first lesson of HRF is that it allows us to see that women do mobilize in high-risk settings, despite the potential for ongoing violence and retribution that this might imply. In other research, I

\footnotetext{
${ }^{64}$ Enrique Arias and Daniel Goldstein, "Violent Pluralism: Understanding the New Democracies of Latin America," in Violent Democracies in Latin America, eds. Enrique Arias and Daniel Goldstein (Durham: Duke University Press, 2010). ${ }^{65}$ Sandvik, Gendering Violent Pluralism, 3.

${ }^{66}$ Ibid., 8.

${ }^{67}$ Kreft, Responding to Sexual Violence: Women's Mobilization in War.
} 
detail the four component parts of HRF, mentioned above; ${ }^{68}$ a full discussion of how women choose to exercise their feminist agency (i.e. the pillars of HRF) is not within the remit of the present article. What is important to underscore, though, is that High Risk Feminism is a local response to conflict dynamics, a grassroots brand of agency from below. In such a climate, we might expect women - often portrayed as weaker or more vulnerable members of society - to shy away from activities that augment their exposure to risk. These women transgress traditional gender barriers and thus expose themselves to the additional risks of high violence, (including targeting by actors for sexualized and violent forms of punishment). ${ }^{69}$ Not only are such women resisting violence, their activism focuses on the pursuit of gender justice, as well as challenging patriarchal culture more generally. ${ }^{70}$

According to classical social movement theorists, though, people would not choose to participate in social movements if there is risk involved in doing so. ${ }^{71}$ This is the common-sense explanation: people will not engage in activities that expose them to personal danger because this is irrational. ${ }^{72}$ In order for action to be justifiable, the participant would have to have the expectation of a positive and measurable outcome to outweigh the cost of action. Risking death or likely personal injury, therefore, defies the logic of collective action. Loveman's 1998 study on human rights defenders mobilizing in the Southern Cone despite authoritarian repression further seeks to answer why people engage in high-risk action. She asks:

If risk or cost is calculated as a high probability of "death," while benefit is calculated at a minimal probability of "maintenance of honor" or "respect for human rights," how is this "ratio" to be assessed in the grammar of rational calculation in order to predict the outcome? If the likely result of action is death, rational choice models would predict inaction, unless they determine ex post facto, with reference to the individual's behavior, that the first order preference is a certain "value" that requires such a sacrifice. This, of course, is tautological. ${ }^{73}$

The point of the present article is not to detail the multiple social movement theories that inform $\mathrm{HRF}^{\prime}$ 's understanding of why women mobilize as feminists in high-risk settings. ${ }^{74}$ Rather, it is to point out that empirical research points convincingly to the fact that women do mobilize, despite the risks that doing so entails.

Beyond simply acting collectively, what is surprising (as Sandvik notes) is that we rarely talk about the agency that women build because of the violence(s) to which they were/are exposed. Indeed, some women mobilize for the first time because of their exposure to conflict dynamics. This was the case with women in the aftermath of genocide in Rwanda and Bosnia, as violence forced them engage in new social roles tied to everyday life, leading them to then form and participate in organizations to support everyday needs, and then leading to participation in formal and informal politics. ${ }^{75}$ These particular groups did not necessarily choose to mobilize before - around inequality or lack of education or land rights (in Colombia, for example $)^{76}-$ but were spurred into

\footnotetext{
${ }^{68}$ Zulver, High-Risk Feminism in El Salvador; Zulver, Building the City of Women; Julia Zulver, "High Risk Feminism in Colombia: Women's Mobilisation in Violent Contexts" (PhD diss., University of Oxford, 2018), accessed November 21, 2019, https://ora.ox.ac.uk/objects/uuid:3fc50c53-d6f5-49c9-a3ba-ca68570a78a3.

${ }^{69}$ Julieta Lemaitre and Kristin Bergtora Sandvik, "Shifting Frames, Vanishing Resources, and Dangerous Political Opportunities: Legal Mobilization among Displaced Women in Colombia," Law and Society Review 49, no. 1 (2015), 5-38.

${ }^{70}$ Zulver, High Risk Feminism in Colombia.

${ }^{71}$ Mancur Olson, The Logic of Collective Action (Cambridge, MA: Harvard University Press, 1965).

${ }^{72}$ Edward Muller and Karl-Dieter Opp, "Rational Choice and Rebellious Collective Action," American Political Science Review 80, no. 2 (1986), 471-488.

${ }^{73}$ Mara Loveman, "High-Risk Collective Action: Defending Human Rights in Chile, Uruguay, and Argentina," American Journal of Sociology 104, no. 2 (1998), 481.

${ }^{74}$ For a full explanation, see Chapter 2 of Zulver, HRF in Colombia.

${ }^{75}$ Marie E. Berry, War, Women, and Power: From Violence to Mobilization in Rwanda and Bosnia-Herzegovina (Cambridge: Cambridge University Press, 2018), 12.

${ }^{76}$ To be clear, I am not implying that women's mobilization (including feminist mobilization) in Colombia is a recent phenomenon, nor that it only arises in situations of high risk. For an overview of Colombian women mobilizing for
} 
action precisely because of their exposure to violence. In my research, I found that being thrust into situations whereby it became apparent that mobilization was a good way to protect themselves (whether or not this protection is real or psychosocial, as will be discussed presently), women were given the incentives to mobilize, despite the ongoing and augmented risk of violent retribution. We know that there is something unique about this mobilization.

Indeed, (drawing on social movement theory) McAdam notes that "the mobilization dynamics of high-risk movements are likely to be qualitatively different from those of low-risk movements."77 Moreover, studies have shown that severe repression may actually stimulate collective action, instead of causing demobilization. ${ }^{78} \mathrm{HRF}$ goes beyond this notion, to posit that conditions of high risk can lead to the creation of a feminist identity that catalyzes mobilization.

In reviewing the ways in which we study and understand women who mobilize or operate in conflict settings (above), we have not encountered explanations that adequately explain why women might act collectively as feminists despite the associated risks of doing so. In high-risk conditions, previously safe spaces for women (like the home, for example) become unsafe. ${ }^{79}$ It is here that women are making the decision to (re)claim their access to safety. In doing so, their encounters of, and experiences with violence - themselves deeply gendered - mean that this mobilization necessarily involves challenging entrenched gendered power dynamics. Fundamentally, then, participating in a mobilization under these circumstances is a feminist act.

This identity is strengthened through participation in mobilization; recursive repertoires entrench a feminist identity for a feminist mobilization. That women's behavior transgresses traditional gender boundaries (particularly in machista Latin America) makes it feminist. Such transgression augments the existing risks of mobilizing in the first place, as opposing actors seek to repress women's transformational aspirations. Furthermore, the pursuit of gender justice puts a target on organization members' heads, as their strategies that denounce perpetrators of violence create a challenge to the status quo of violence. ${ }^{80}$ Importantly, these women are not mobilizing for others (necessarily), but rather, for themselves.

It is important, again, however, not to flatten the categories of "woman" or "feminist." The women of AFROMUPAZ in Bogotá, for example, have a complicated relationship with the term feminism, which for them refers to a formalized or institutionalized - and largely white, Western - project to which they do not ascribe. Rather, they celebrate feminism in "cuerpo y cara de mujer" (with a woman's body and face), a category that is deeply tied up with Afro-Colombian racial identity. ${ }^{81}$ The Colectiva Matamba in Bogotá contends with inter-group differences regarding feminism, as outlined by an interviewee:

peace, see Kate Paarlberg-Kvam, "What's to Come Is More Complication: Feminist Visions of Peace in Colombia," International Feminist Journal of Politics 21, no. 2 (2019), 194-223.

77 Thus, while HRF does exist on a spectrum, it is not appropriate to necessarily speak of "low risk feminism" as a point of comparison. McAdam, 1986, in Loveman, High Risk Collective Action, 487.

${ }^{78}$ Loveman, High-Risk Collective Action. For an in-depth discussion of how exactly women make the decision to join HRF organizations, despite the risks this entails, see Chapter 2 of Zulver, HRF in Colombia.

${ }^{79}$ Indeed, this opens up an interesting discussion about violence in the "public" vs. "private" sphere. Is intimate partner violence (IPV) included in a definition of high risk? In the Colombian case, being expelled from one's home (displaced) naturally involves a blending of public and private domains. Hume's study on El Salvador argues that violence against women lies on the knife's edge between public and private and adds says that women's experiences are often invalidated by wider society for violating a system of 'patriarchal privacy.' Mo Hume, The Politics of Violence: Gender, Conflict, and Community in El Salvador (West Sussex: Wiley-Blackwell, 2009). In the present case studies, high risk (as defined below) is a subjective category that lies in participants' understandings of how particular actions will expose them to violent reprisals. It is not beyond the realm of possibilities that augmented rates of IPV might influence a woman's perception of the risk she is undertaking by engaging in collective action. Indeed, further research on the linkages between public and private violence and subsequent assessments of risk would be illuminating for future studies on HRF. For a comprehensive study on perceived agency vs. passivity, see Mo Hume and Polly Wilding, "Beyond Agency and Passivity: Situating a Gendered Articulation of Urban Violence in Brazil and El Salvador," Urban Studies (2019), 1-18.

${ }^{80}$ For an example in Putumayo, Colombia, see Julia Zulver, "Women Weaving Life in Southern Colombia," NACLA, April 11, 2019, accessed November 21, 2019, https://nacla.org/news/2019/04/11/women-weaving-life-southern-colombia.

${ }^{81}$ Julia Zulver, “Asociación de Mujeres Afro Por La Paz (AFROMUPAZ): Differential Feminism in Cuerpo y Cara de Mujer," Latin American Perspectives, forthcoming. 
..."There are some members of the Colectiva who don't call themselves feminists...this is because we have had lots of struggles with white feminists in the past. They only defend what they consider women's rights...." "Feminism is a political movement that fights for social equality...but when Black women have never [properly] been understood as women, I can't buy into this understanding." 82

These differences do not necessarily impede women's ability to form a collective identity that permits collective action. Indeed, collective identity formation in the face of threats is one of the take-away lessons of HRF. With that said, it is important to unpack what feminism means and how it interacts with intersectional identities in order to avoid falling into the same reductionist trap that I critique in this article.

This leads me to reflect on the work of Levitt and Merry, who examine "how ideas and strategies generated by human rights and global feminist movements are vernacularized to fit particularly historical and social contexts." 83 They interrogate the trends to focus on "top down" cultural transfer, and instead call for a focus on how global rights packages need to be vernacularized for local cultural repertoires. This seems fitting when discussing atrocity crime and genocide prevention; both critical studies and practical efforts should be able to unpack the intersectional nuances related to local context, identity, experience, and agency. These themes are compelling discussed by Mertens and Myrttinen in their article on SGBV policy and programming in the DR Congo. They examine how the humanitarian sector, by placing primary attention on conflict-related rape of women and girls as opposed to other, more nuanced forms of gender-based violence, "wittingly or unwittingly [reproduces] heteronormative and neo-liberal understandings of what a "proper' individual and family should look like..." and how this reproduction is not necessarily congruent with the "lived realities of the affected communities in question." 84

\section{Women Develop Sophisticated and Nuanced Senses of Agency, Resilience, and Purpose}

HRF goes beyond the simple assertion that some women mobilize in high-risk contexts (when we might not expect them to do so). It is a feminist strategy of resistance that offers women the ability to reconstruct (intersectional) identities and create an empowering sense of agency during seemingly out of control circumstances.

In an article that reflects on measurements of women's empowerment, Kabeer offers a nuanced definition of agency. This definition is multidimensional:

Agency is about more than observable action; it also encompasses the meaning, motivation, and purpose which individuals bring to their activity, their sense of agency, or 'the power within'... it refers to people's capacity to define their own life-choices and to pursue the own goals, even in the face of opposition from others. ${ }^{85}$

It allows us to understand that the conflict-affected context in which women operate is constrained by myriad (gendered) power dynamics. These dynamics victimize women and make them feel powerless. Moreover, they shape their ability to make choices. Joining a HRF organization amplifies the range of choices that women are able to make. Not only does participation in an HRF organization highlight that "the pain of one is the pain of all" 86 , but women victims of the conflict

${ }^{82}$ Julia Zulver, "Colectiva Matamba: The Afro-Colombian Women's Collective Mobilizing Against Structural Racism," NACLA 50, no. 4 (2018), 377-380.

${ }^{83}$ Peggy Levitt and Sally Merry, "Vernacularization on the Ground: Local Uses of Global Women's Rights in Peru, China, India, and the United States," Global Networks 9, no. 4 (2009), 443.

${ }^{84}$ Charlotte Mertens and Henri Myrttinen, “'A Real Woman Waits' - Heteronormative Respectability, Neo-Liberal Betterment and Echoes of Coloniality in SGBV Programming in Eastern DR Congo," Journal of Intervention and Statebuilding 13, no. 4 (2019), 418-439. Doi:10.1080/17502977.2019.1610992

${ }^{85}$ Naila Kabeer, "Resources, Agency, Acheivements: Reflections on the Measurement of Women's Empowerment," Development and Change 30 (1999), 438.

${ }^{86}$ Maya Thomas Davis and Julia Zulver, “Colombia's City of Women,” Al Jazeera, December 11, 2015, accessed November 21, 2019, http://www.aljazeera.com/indepth/features/2015/12/colombia-city-women-151211085034832.html. 
are able to find (real and/or perceived) safety in community. There are both material and nonmaterial (psychosocial) benefits to joining, and ultimately these become more important in the victim's life -and indeed to her identity ${ }^{87}$ - than does avoiding the augmented risks that come with mobilizing. HRF organizations allow women to individually and collectively develop resilience.

Indeed, when Bridget Conley-Zilkic asks "who is the subject of atrocities prevention?" she draws on the concept of resilience and cites Pain and Levine ${ }^{88}$ when she notes: "the term can be used to describe the ability of a community or individual to alternatively avoid collapse, recover, or adapt." ${ }^{89}$ In order to gain more insight into this resilience, Pain and Levine continue, we must "focus on reducing people's vulnerability and enhancing their agency" within a context whereby people's choices and actions are constrained by inequality and exclusion..$^{90}$

Here, however, it is important to put some meat on the bones of concepts like "resilience." As Elisa von Joeden-Forgey notes: "Because gender operates in ways that are often unspoken, gender research requires that we interpret the nature of the forces and processes we study through myriad means that go well beyond the language of the actors involved." ${ }^{91}$ She suggests that gender research allows us to read genocide from the bottom up, which is a valuable contribution to genocide prevention efforts. ${ }^{92} \mathrm{HRF}$ can add to this conversation by studying the agency that some women themselves develop during and after experiences of trauma. In assessing how women choose to be the protagonists in their own futures, we can extrapolate on the most effective ways to support these efforts. Given the dynamics of war and conflict, most of the women with whom I have conducted fieldwork have felt, and continue to feel ${ }^{93}$, systematically ignored by the state. They further feel that their differential needs have not been considered by either the state or aid agencies.

For example, in Sueño de Vida Digna ${ }^{94}$, a report about the history of the Liga de Mujeres Desplazadas, Guerrero (the leader of the organization) writes about the ways in which aid provided by the Catholic Church was ignorant to the specific needs of women (especially those who had suffered sexual violence). For example, the Church did not provide aid that related to women's sexual and reproductive health (including condoms or sanitary products). In a zone where women were highly vulnerable to sexual abuse, she notes that the Church judged and stigmatized women who had become pregnant: "From that moment on, we decided to manage our own humanitarian aid, whose meaning would be re-defined by [the very women it was intended to reach]." ${ }^{\prime 5}$

HRF organizing develops a strong sense of collective identity focused around survivorship, self-dependence, autonomy, and agency. It is about identity, about taking control of seemingly out of control circumstances to create - essentially from nothing - an agency that was taken away from them during periods of violence and displacement. HRF offers a lens through which to see the independent strategies that women in high-risk contexts have adopted. Indeed, when women felt the most isolated and the most abandoned - times in which their specific gendered needs were not considered by either the state or aid agencies - they decided to come together in the pursuit of

\footnotetext{
${ }^{87}$ For more on how ongoing participation in an organization informs identity, see Javier Auyero, Contentious Lives: Two Argentine Women, Two Protests, and the Quest for Recognition (Durham: Duke University Press, 2003); Simón Escoffier, "Mobilisational Citizenship: Sustainable Collective Action in Underprivileged Urban Chile," Citizenship Studies 22, no. 7 (2018), 1-22.

${ }^{88}$ Adam Pain and Simon Levine, "A Conceptual Analysis of Livelihoods and Resilience: Addressing the 'Insecurity of Agency'," HPG Working Paper (London: Overseas Development Institute, 2012).

${ }^{89}$ Bridget Conley-Zilkic, "Who Is the Subject of Atrocities Preention?," Global Responsibility to Protect 6 (2014), 430-452.

${ }^{90}$ Pain and Levine, Livelihoods and Resilience, 10.

${ }^{91}$ von Joeden-Forgey, Gender and the Future, 96.

92 Ibid., 95.

${ }^{93}$ In this case of the Liga, this is particularly pertinent when it comes to ongoing promises of collective reparations that have never materialized. See Julia Zulver, "Feasible Justice? How to Guarantee Reparations for Colombia's 8.3 Million Victims," JusticeInfo.Net, 2018, accessed November 21, 2019, https://www.justiceinfo.net/en/justice-reconciliation/37686feasible-justice-has-colombia-over-promised-and-under-delivered-reparations-for-its-8-6-million-vic.html.

${ }^{94}$ Julieta Lemaitre et al., Sueño de Vida Digna: La Liga de Las Mujeres Desplazadas (Bogotá: Universidad de los Andes, 2014).

${ }^{95}$ Ibid., 85.
} 
gender justice.

Recognizing What Women Want:

As mentioned above, women suffer conflicts differentially. When violence is widespread and gendered, women are left in situations that are different from those of men. For example, in the Colombian case, Meertens notes:

The armed conflict has had a considerable and disproportionate impact on women, as they suffer specific risks and confront specific vulnerability because of their gender. Examples include: forced displacement in conditions of marital abandonment or widowhood (leading to an increasing number of women-headed households in displaced populations in cities); gender-based violence and especially sexual violence by armed actors as a weapon of war; the imposition of patriarchal models of social control by local power holders; and the historical lack of recognition of women's rights that has facilitated their dispossession and violent seizure of their land. ${ }^{96}$

${ }^{96}$ Meertens, Forced Displacement, 154. 
Beyond this, however, and given the protracted nature of the conflict and its legacies (Nordstrom's "tomorrows of violence"), ${ }^{97}$ individual women can feel helpless, abandoned by the state. We saw this in the section above; one of the outcomes of longstanding feelings of abandonment by the state led to women developing an identity and a sense of agency that is both autonomous and independent.

The development of this agency, identity, and purpose, however, means that women also have formulated demands. They have spent decades fighting for their basic needs and for gender justice, despite the exposure to violence that this has involved. As such, HRF organizations foster a "no research about us without us" ethos. Molyneux recognizes that "one lesson that can be drawn from the experience of working with women's organization is that the question of ownership is central." 98 She notes that it is not effective to impose external programs, projects, and goals: "the question of the "ownership" of projects and goals as well as participants' identification with the values of the project are all critical to its success." ${ }^{\prime 99}$

McEvoy and McConnachie warn us against co-opting women's agency during transitional justice processes. They discuss dynamics in which "transitional justice entrepreneurs" speak on behalf of victims and seek to represent victims without problematizing the power relations at play. ${ }^{100}$ This is arguably a similar dynamic to the (masculine) dynamics of genocide prevention. This falls into traps outlined by Spivak in which the subaltern is not able to speak or represent herself. ${ }^{101}$ Importantly, interlocutors run the risk of "re-silencing victims, negating their potential agency, and reproducing a sense of powerlessness." 102 Beyond re-silencing, there is also a risk in post-conflict situations of revictimizing survivors.

Broadly speaking, then, this section has shown that women who mobilize - including in nonprofessionalized, grassroots ways - do know what they want. ${ }^{103}$ They have years of operating in dire circumstances, and through this experience have developed sophisticated, nuanced senses of agency and resilience. As such, any interventions or policies need to respect this history. Indeed, Sandvik and Lemaitre ask: "who gathers evidence on humanitarian crises? What counts as evidence? How is evidence used?"104 Their article outlines a study whereby a group of women was able to develop its own research data and use this to advance its own agenda in its interactions with donor bodies and the government; "beneficiaries of humanitarian aid can, and do, use participatory research to advance their own ends in the legal and political spaces created around humanitarian crisis." 105 Studies like this highlight that: "beneficiaries' priorities and agency in the production of data on humanitarian crises are in need of further study."106

\section{Informing Intervention: Resilience and Women's Agency}

The above three points - (1) that women do mobilize despite (and because of) violent contexts, (2) that women have developed sophisticated and nuanced identities based on their autonomous agency, and (3) that women know what they want in both ongoing and post-conflict situations - are salient lessons that have policy and intervention repercussions. The take-away lessons are examined in this final section.

\footnotetext{
${ }^{97}$ Carolyn Nordstrom, "The Tomorrow of Violence," in Violence, ed. Neil Whitehead (Santa Fe: School of American Research Press, 2004), 223-242.

${ }^{98}$ Molyneux, Women's Grass-Roots Organisations, 8.

${ }^{99}$ Ibid.

${ }^{100}$ Kieran McEvoy and Kirsten McConnachie, "Victims and Transitional Justice: Voice, Agency and Blame," Social \& Legal Studies 22, no. 4 (2013), 498.

${ }^{101}$ Gayatri Chakravorty Spivak, “Can the Subaltern Speak?," in Marxism and the Interpretation of Culture, eds. Cary Nelson and Lawrence Grossberg (Urbana: University of Illinois Press, 1988), 271- 316.

${ }^{102}$ McEvoy and McConnachie, Victims and Transitional Justice.

${ }^{103}$ The specificities of what they want naturally differ by context and circumstance.

${ }^{104}$ Kristin Bergtora Sandvik and Julieta Lemaitre, "Internally Displaced Women as Knowledge Producers and Users in Humanitarian Action: The View from Colombia," Disasters 37, no. 1 (2013), 36-50.

${ }^{105}$ Ibid., 36.

${ }^{106}$ Ibid., 46.
} 
As mentioned, Pain and Levine examine the concept of 'resilience' and the hope that 'resiliencebuilding' can "help bridge the persistent and much-criticized divide between emergency response and development assistance."107 They note that much of these discussions take place within humanitarian circles, in crisis- and disaster-prone areas. Their paper argues, however, that instead of focusing on building resilience, conceptual coherence will be more available if humanitarian debates focus on reducing vulnerability and enhancing agency. They continue: "while resilience has value as an organizing concept or mobilizing metaphor, analytically it has rather less traction unless the discussion can move to one of understanding agency and the capacity of people to act.".108

There is compelling evidence that shows that this agency exists independently of outside intervention. Women like those I worked with in Colombia have historically demonstrated their ability to act collectively in the absence of resources or support. As such, when it comes to organizations and actors who do want to intervene, such interventions should be framed within a relationship of alliance. Women have already laid the groundwork and put in the effort - instead of reinventing the wheel, agencies and actors should recognize the organizations' autonomy and find creative approaches to being allies rather than co-opting them or attempting to represent their struggles and their demands. Figure 1 represents a mural designed and painted by a women's organization, the Alianza de Mujeres Tejedoras de Vida, in Bajo Putumayo, Colombia. Here, they remember their dead, and they highlight their resilience with a text that reads: "They pulled out our fruits, they cut our branches, they burned our trunks, but they were not able to kill our roots." The women continue to be threatened with violence and death by illegal armed actors in the region because of their community activism. Preliminary research in November 2018, however, points to a relationship that suggests the organization is able to effectively "vernacularize" and claim agency and autonomy over the values packages promoted by the international organizations who sponsor it (for example, the UNHRC). ${ }^{109}$

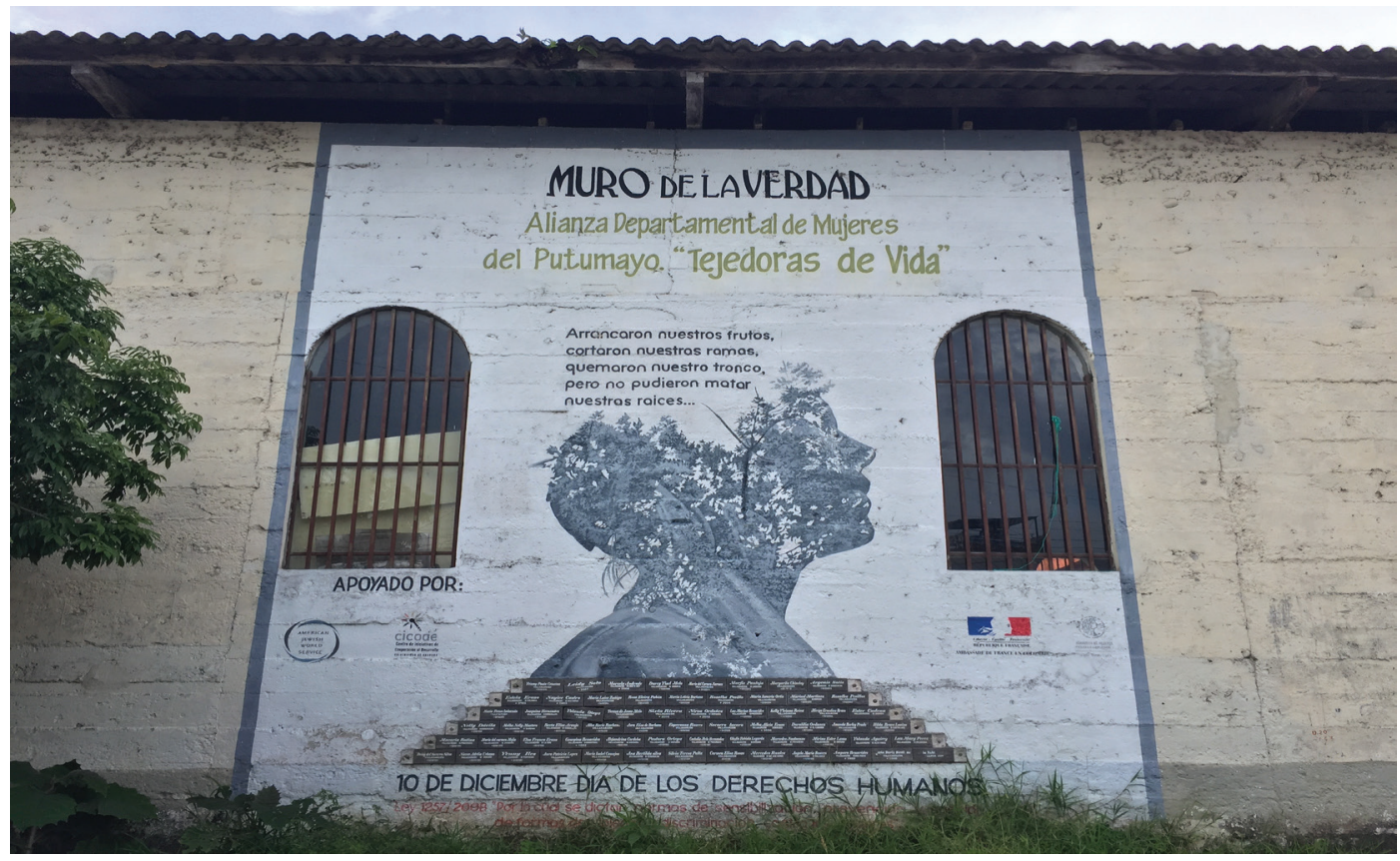

This Truth Mural, which includes the names of women murdered during the conflict, was painted by the Alianza de Mujeres Tejedoras de Vida in Putumayo, Colombia. (Villagarzón, Putumayo, November 2018. Credit: Julia Zulver).

\footnotetext{
${ }^{107}$ Pain and Levine, Livelihoods and Resilience.

${ }^{108}$ Ibid., 11.

${ }^{109}$ Zulver, Women Weaving Life.
} 
Pain and Levine conclude their article by noting that a focus on people's agency ("their ability to make their own choices") will allow policymakers to design policies and interventions that "reduce as far as possible the degree to which people live in 'dependent security', and the degree to which they can be helped to have greater 'autonomous security."' Indeed, they continue, "this would also ensure that policy and interventions are properly grounded in the lives of the people affected by crises, and in the their wider political-economy context." ${ }^{110}$ Indeed, Albright and Cohen highlight that one of the strategies for preventing genocide is to strengthen social and institutional safeguards: "a strong civil society will provide a bulwark against the designs of conflict entrepreneurs." 111 Accordingly, groups that promote women's rights should "be a particular focus of assistance efforts." ${ }^{112}$

What, then, can the emergent lessons of HRF offer to genocide and atrocity crime prevention? In order to assess this question, I am drawn to reflect on a new initiative led by the Canadian government. In 2017, the government of Justin Trudeau announced Canada's new Feminist International Assistance Policy. ${ }^{113}$ This policy claims that "Canadians are safer and more prosperous when more of the world shares our values. Those values include feminism and the promotion of the rights of women and girls." 114 Canada's feminist approach to international assistance "has committed to support that which is human-rights based, strategic and focused, transformative ${ }^{115}$ and activist, and evidence-based and accountable."116 The country's efforts specifically make the commitment to employ evidence-based decision-making through better data collection and evaluation of gender equality, which includes a $\$ 150$ million investment (over five years) into policy research, data collection, and evaluation. ${ }^{117}$

Starr and Mitchell, themselves Canadian researchers of sexual violence in Ethiopia, ask what better data collection and evaluation of gender equality might mean "in the context of an explicitly feminist international assistance policy." 118 Their article concludes with a hopeful outlook: “[Canada's] feminist assistance policy has an excellent chance of doing something right ... if the idea of advocacy for the local through participatory approaches with women (rather than about women) is supported financially and in spirit."119

As a feminist Canadian researcher myself, I too share their enthusiasm. As a note of caution: adding women's voices or listening to women should not be considered policy panaceas. Indeed, these should also not be considered synonymous to full gender analysis of the dynamics of violence (including a focus on masculinities). ${ }^{120}$ The Feminist International Assistance Policy may be the opportunity to move away from models of intervention and development that seek to "add women and stir" and instead actually seek to untangle the nuances and specificities of women's agency in

\footnotetext{
${ }^{110}$ Pain and Levine, Livelihoods and Resilience.

${ }^{111}$ Madeleine Albright and William Cohen, Preventing Genocide: A Blueprint for U.S. Policymakers (Washington, DC: United States Holocaust Memorial Museum, the American Academy of Diplomacy, and the Endowment of the United States Institute of Peace, 2008), 41.

${ }^{112}$ Ibid., 49.

${ }^{113}$ Government of Canada, Canada's Feminist International Assistance Policy (Ottawa: Global Affairs Canada, 2017), accessed November 9, 2019, http://international.gc.ca/world-monde/issues development-enjeux developpement/prioritiespriorites/policy-politique.aspx?lang=eng.

${ }^{114}$ Ibid.

${ }^{115}$ For a thorough investigation of what 'transformative' means in the case of the Canadian Feminist International Assistance Policy, see Danielle Lee, "What Is Feminist Foreign Policy: Analysis of Canada's Feminist International Assistance Policy" (master's thesis, University of Ottawa, 2018), accessed November 21, 2019, www.ruor.uottawa.ca/ bitstream/10393/37379/1/Lee Danielle 2018 thesis.pdf.

${ }^{116}$ Lisa Starr and Claudia Mitchell, "How Can Canada's Feminist International Assistance Policy Support a Feminist Agenda in Africa? Challenges in Addressing Sexual Violence in Four Agricultural Colleges in Ethiopia," AgendaEmpowering Women for Gender Equity 32, no. 1 (2018), 107-118.

${ }^{117}$ Ibid., 108.

${ }^{118}$ Ibid., 115. Announced its new "feminist international assistance policy" towards achieving the United Nations Sustainable Development Goals (SDGs).

${ }^{119}$ Ibid.

${ }^{120}$ Theidon, Reconstructing Masculinities; Theidon, 1325+17=?
} 
conflict settings. As Albright and Cohen suggest, finding effective ways to support women and the "integral role" they play in civil society may in fact serve to mitigate the risks of conflict. ${ }^{121}$

What's more, as Starr and Mitchell point out, Canada is not the only country that is taking steps toward including gender inequality more substantially within its international assistance programs. The United Kingdom has a new Special Envoy for Gender Equality, Sweden has a new policy framework for development that includes global gender inequality, Norway has an Action Plan for Women's Rights and Gender Equality in Foreign and Development Policy, Australia has a Gender Equality and Women's Empowerment Strategy. ${ }^{122}$ Given this host of opportunities to involve women, to recognize their agency and their needs, and to support them in building safer worlds for themselves, I hope that there is indeed reason to be optimistic about a future in which women's grassroots and local approaches to gender justice are adequately bolstered and supported by international allies.

\section{Conclusion}

As mentioned above, HRF is not a prescriptive framework. It is further not the goal of this article to outline a replicable, step-by-step plan under which women will decide to build and fortify a uniquely feminist style of agency. Rather, it offers us a chance to reflect on how, in the actual or perceived absence of any other source of aid, certain women choose to make their own decisions and take care of themselves, despite the ongoing risks to which this exposes them. This has repercussions that relate to genocide and atrocity crime prevention; listening to women's experiences of violence and focusing on grounded responses to this same violence might provide insight about how to engage in preventative practice. In turn, this will move us away from gendered essentialism that relegates women to the instrumentalizing role of peacebuilders.

Sandvik notes: "there can and should be many theories on the gender of violent pluralism." 123 High Risk Feminism is one of these theories; it presents a new lens through which to study women's mobilization and agency. Instead of viewing women solely as victims of the conflict, or through their capacity to act as mothers (or on behalf of others), the framework allows for a nuanced reading of women as survivors, activists, and luchadoras (fighters) in contexts of high risk. This is an example of resilience and also of agency-building. It fulfills the imperative outlined by Pain and Levine to focus on interventions that are grounded in every day realities, and expands on Levitt and Merry's call to avoid "top down" focuses on cultural (values packages) transfer.

The value of HRF, then, is that it considers not only that mobilization can take place in high-risk contexts and improves the life of women, but also why and how such mobilization can take place. Prevention interventions and programs - for example, like the Canadian International Feminist Assistance Policy - do not need to reinvent the wheel but can rather offer support to strategies that have been developed and established throughout years of struggle.

Indeed, my research in Colombia and El Salvador shows that in the absence of support, women autonomously organized themselves into collectives that provide both material and non-material benefits that give purpose and meaning to daily life. These organizations further provide a sense of agency; the ability (or the perceived ability) to overcome the "tomorrows of violence" provides hope for a better future. This feminist resistance moves beyond national peacebuilding projects and contributes, at the grassroots level, to a larger gender justice project that calls for the undoing of historic and engrained patterns of inequality.

While my research focuses on Latin America, there are plenty of conflict situations that could potentially benefit from research that searches for local, feminist responses to (gender) violence and conflict. Bearing in mind the HRF framework, scholars and policymakers could dedicate time to identifying islands of feminist agency in high-risk contexts where we might not expect mobilization for gender justice. A quick scan of newspaper headlines shows us that women are taking matters into their own hands and seeking autonomous - and I would argue, feminist -

\footnotetext{
${ }^{121}$ Albright and Cohen, Preventing Genocide.

${ }^{122}$ Starr and Mitchell, Canada's Feminist International Assistance Policy.

${ }^{123}$ Sandvik, Gendering Violent Pluralism, 13.
} 
security in the context of ongoing violence. From women's only villages in Kenya where women go to escape sexual violence, ${ }^{124}$ to tents that offer feminist education in women friendly spaces in insurgent destroyed towns in the Philippines, ${ }^{125}$ to a City of Women in a northern Colombian conflict zone, ${ }^{126}$ we can see myriad examples where women are creating spaces in which to learn about their rights and to generate a collective feminist identity. These spaces offer reprieve from spaces where gendered violence is pervasive and ubiquitous. Accordingly, frameworks like HRF add to a larger conversation about how to include marginalized, silenced, or forgotten voices into debates about prevention, inclusion, and justice.

Violence, atrocity crimes, and genocide present ongoing challenges to many women's everyday lives. If there is the possibility to translate academic research on HRF mobilization into action that modifies the intensity of the "tomorrows of violence", it is imperative that it be undertaken. Leaving the lessons of resistance, resilience, and agency on paper would be doing a disservice to those women who have suffered - and resisted - during and in the aftermath of violent conflict.

\section{Acknowledgments}

The author wishes to thank Andrew Woolford, Alex Hinton, the participants at the Critical Genocide Prevention Workshop (University of Manitoba, October 2018), and the two anonymous reviewers for their insightful comments and suggestions. She also wishes to thank Roxani Krystalli for her thoughtful insights.

\section{Bibliography}

Alba, Magali, Jan Boesten, Annette Idler, Juan Masullo, Arlene Tickner, and Julia Zulver. "Challenges in Colombia's Changing Security Landscape: Toward a Shared Vision of Peace." LASA Forum 49, no. 3 (2018), 75-80.

Albright, Madeleine, and William Cohen. Preventing Genocide: A Blueprint for U.S. Policymakers. Washington, D.C.: United States Holocaust Memorial Museum, the American Academy of Diplomacy, and the Endowment of the United States Institute of Peace, 2008.

Arias, Enrique, and Daniel Goldstein. "Violent Pluralism: Understanding the New Democracies of Latin America." In Violent Democracies in Latin America, edited by Enrique Arias and Daniel Goldstein. Durham: Duke University Press, 2010. Doi: 10.3138/cjh.45.3.678

Aroussi, Sahla. "Women, Peace and Security: Moving Beyond Feminist Pacifism." Presentation, 2009. PSA Annual Conference.

Auyero, Javier. Contentious Lives: Two Argentine Women, Two Protests, and the Quest for Recognition. Durham: Duke University Press, 2003. Doi: 10.1215/9780822384366

Baines, Erin. “'Today, I Want to Speak Out the Truth': Victim Agency, Responsibility, and Transitional Justice." International Political Sociology 9, no. 4 (2015), 1-17. Doi: 10.1111/ ips.12100

Berry, Marie E. War, Women, and Power: From Violence to Mobilization in Rwanda and BosniaHerzegovina. Cambridge: Cambridge University Press, 2018.

Berry, Marie E., and Trisha R. Rana. "What Prevents Peace? Women and Peacebuilding in Bosnia and Nepal." Peace and Change 44, no. 3 (2019), 321-349.

Bindel, Julie. "The Village Where Men Are Banned." The Guardian, August 16, 2015. Accessed November 21, 2019. https://www.theguardian.com/global-development/2015/aug/16/ village-where-men-are-banned-womens-rights-kenya.

Boesten, Jelke, and Polly Wilding. "Transformative Gender Justice: Setting an Agenda." Women's Studies International Forum 51 (2015), 75-80. Doi: 10.1016/j.wsif.2014.11.001

Buss, Doris. "The Curious Visibility of Wartime Rape: Gender and Ethnicity in International Criminal Law." Windsor Yearbook of Access to Justice 25, no. 1 (2007), 3-22.

Carpenter, Charli. "Beyond 'Gendercide': Incorporating Gender into Comparative Genocide Studies." The International Journal of Human Rights 6, no. 4 (2002), 77-101. Doi: $\underline{10.1080 / 714003779}$

Casey, Nicholas. "Colombia Army's New Kill Orders Send Chill Down Ranks." New York Times, May 18, 2019. Accessed November 21, 2019. www.nytimes.com/2019/05/18/world/ americas/colombian-army-killings.html. 
Castillo-Diaz, Pablo, and Hanny Cueva-Beteta. "The Promise and Limits of Indicators of Women, Peace and Security." In The Oxford Handbook of Gender and Conflict, edited by Fionnuala Ní Aoláin, Naomi Cahn, Dina Francesca Haynes, and Nahla Valji, 185-198. Oxford: Oxford University Press, 2018. Doi: 10.1093/oxfordhb/9780199300983.013.15

Centro Nacional de Memoria Histórica. "El Placer: Mujeres, Coca, y Guerra En El Bajo Putumayo." Bogotá: Centro Nacional de Memoria Histórica, 2012. Accessed November 21, 2019. http:// babel.banrepcultural.org/cdm/ref/collection/p17054coll2/id/116.

--------. "La Guerra Inscrita En El Cuerpo: Informe Nacional de Violencia Sexual En El Conflicto Armado." Bogotá: Centro Nacional de Memoria Histórica, 2017.

Cockburn, Cynthia. "Sexual Violence in Bosnia: How War Lives on in Everyday Life." OpenDemocracy, November 28, 2013. Accessed November 21, 2019. www.opendemocracy. net/en/5050/sexual-violence-in-bosnia-how-war-lives-on-in-everyday-life/.

--------. "War and Security, Women and Gender: An Overview of the Issues." Gender \& Development 21, no. 3 (2013), 433-452. Doi:10.1080/13552074.2013.846632

Cohn, Carol. "'Maternal Thinking' and the Concept of 'Vulnerability' in Security Paradigms, Policies, and Practices." Journal of International Political Theory 10, no. 1 (2013), 46-69. Doi: $\underline{10.1177 / 1755088213507186}$

Conley-Zilkic, Bridget. "Who Is the Subject of Atrocities Prevention?" Global Responsibility to Protect 6 (2014), 430-452. Doi: 10.1163/1875984X-00604005

de Waal, Alex, Jens Meierhenrich, and Bridget Conley-Zilkic. "How Mass Atrocities End: An Evidence-Based Counter-Narrative." The Fletcher Forum of World Affairs 36, no. 1 (2012), 15-31.

Elshtain, Jean Bethke. "The Mothers of the Disappeared: An Encounter with Antigone's Daughters." In Finding a New Feminism: Rethinking the Woman Question for Liberal Democracy, edited by Pamela Grande Jensen, 129-149. Lanham: Rowman \& Littlefield Publishers, Inc., 1996.

Escoffier, Simón. "Mobilisational Citizenship : Sustainable Collective Action in Underprivileged Urban Chile." Citizenship Studies 22, no. 7 (2018), 1-22. Doi: 10.1080/13621025.2018.1508412

Gibbings, Sheri Lynn. "No Angry Women at the United Nations: Political Dreams and the Cultural Politics of the United Nations Security Council Resolution 1325." International Feminist Journal of Politics 4 (2011), 522-538. Doi: 10.1080/14616742.2011.611660

Giles, Wenona, and Jennifer Hyndman. Sites of Violence: Gender and Conflict Zones. Berkeley and Los Angeles: University of California Press, 2004.

Goetz, Anne Marie, and Rob Jenkins. "Agency and Accountability: Promoting Women's Participation in Peacebuilding." Feminist Economics 22, no. 1 (2016), 211-236. Doi: $\underline{10.1080 / 13545701.2015 .1086012}$

---------. "Participation and Protection: Security Council Dynamics, Bureaucratic Politics, and the Evolution of the Women, Peace, and Security Agenda." In The Oxford Handbook of Gender and Conflict, edited by Fionnuala Ní Aoláin, Naomi Cahn, Dina Francesca Haynes, and Nahla Valji, 119-131. Oxford: Oxford University Press, 2018. Doi: 10.1093/ oxfordhb/9780199300983.013.9

González, Victoria, and Karen Kampwirth. Radical Women in Latin America: Left and Right. University Park: Pennsylvania State University Press, 2001.

Government of Canada. Canada's Feminist International Assistance Policy. Ottawa: Global Affairs Canada, 2017. Accessed November 9, 2019. http://international.gc.ca/world-monde/issues development-enjeux developpement/priorities-priorites/policy-politique.aspx?lang=eng.

Grupo de Memoria Histórica. “La Masacre de Bahía Portete: Mujeres Wayuu En La Mira.” Bogotá: Editor Aguilar, 2010.

Hill, Felicity. "Women's Contribution to Conflict Prevention and Early Warning and Disarmament." Women, Men, Peace, and Security 4 (2003), 17- 24. Accessed November 9, 2019. https://www. unidir.org/files/publications/pdfs/women-men-peace-and-security-en-565.pdf.

Hinton, Alexander. "Afterword: Wonder Woman, the Gutter, and Critical Genocide Studies." In Memory and Genocide: On What Remains and the Possibility of Representation, edited by Fazil Moradi, Ralph Bucherhorst, and Maria Six-Hohenbalken. New York: Routledge, 2017. Doi: 
$10.4324 / 9781315594897$

-----. "Critical Genocide Studies." Genocide Studies and Prevention 7, no. 1 (2012), 4-15.

Hume, Mo. "The Myths of Violence: Gender, Conflict, and Community in El Salvador." Latin American Perspectives 35, no. 5 (2008), 59-76. Doi: 10.1177/0094582X08321957

--------. The Politics of Violence: Gender, Conflict, and Community in El Salvador. West Sussex: WileyBlackwell, 2009.

Hume, Mo, and Polly Wilding. "Beyond Agency and Passivity: Situating a Gendered Articulation of Urban Violence in Brazil and El Salvador." Urban Studies, 2019, 1-18.

Jacobs, Susie, Ruth Jacobson, and Jennifer Marchbank. States of Conflict: Gender, Violence, and Resistance. New York: Zed Books, 2000.

Jaquette, Jane. "Conclusion: Women's Political Participation and the Prospects for Democracy." In The Women's Movement in Latin America: Participation and Democracy, edited by Jane Jaquette, 223-238. New York: Westview Press, 1994. Doi: 10.2307/2516907

Joeden-Forgey, Elisa von. "Gender and the Future of Genocide Studies and Prevention." Genocide Studies and Prevention 7, no. 1 (2012), 89-107. Doi: 10.1353/gsp.2012.0002

Jones, Adam. "Gender and Genocide in Rwanda." Journal of Genocide Research 4, no. 1 (2002), 65-94.

Kabeer, Naila. "Resources, Agency, Acheivements: Reflections on the Measurement of Women's Empowerment." Development and Change 30 (1999), 435-464. Doi: 10.1111/1467-7660.00125

Kampwirth, Karen. Feminism and the Legacy of Revolution: Nicaragua, El Salvador, Chiapas. Athens: Ohio University Press, 2004.

. Women and the Guerrilla Movements: Nicaragua, El Salvador, Ciapas. Athens: Centre for International Studies, Ohio University, 2006.

Kaplan, Oliver. Resisting War: How Communities Protect Themselves. Cambridge: Cambridge University Press, 2017.

Kirby, Paul, and Laura J. Shepherd. "The Futures Past of the Women, Peace and Security Agenda." International Affairs 92, no. 2 (2016), 373-392. Doi: 10.1111/1468-2346.12549

Kreft, Anne-Kathrin. "Responding to Sexual Violence: Women's Mobilization in War." Journal of Peace Research 56, no. 2 (2019), 220-233. Doi: 10.1177/0022343318800361

Lake, Milli. Strong NGOs and Weak States: Pursuing Gender Justice in the Democratic Republic of Congo and South Africa. Cambridge: Cambridge University Press, 2018. Doi: 10.1017/9781108297745

Lee, Danielle. "What Is Feminist Foreign Policy: Analysis of Canada's Feminist International Assistance Policy." Master's thesis, University of Ottawa, 2018. Accessed November 21, 2019. https://ruor.uottawa.ca/bitstream/10393/37379/1/Lee Danielle 2018 thesis.pdf.

Lemaitre, Julieta, and Kristin Bergtora Sandvik. "Shifting Frames, Vanishing Resources, and Dangerous Political Opportunities: Legal Mobilization among Displaced Women in Colombia." Law and Society Review 49, no. 1 (2015), 5-38. Doi: 10.1111/lasr.12119

Lemaitre, Julieta, Kristin Bergtora Sandvik, Eva Sol López, Juan Pablo Mosquera, Juliana Vargas Gómez, and Patricia Guerrero. Sueño de Vida Digna: La Liga de Las Mujeres Desplazadas. Bogotá: Universidad de los Andes, 2014.

Levitt, Peggy and Sally Merry. "Vernacularization on the Ground: Local Uses of Global Women's Rights in Peru, China, India, and the United States." Global Networks 9, no. 4 (2009), 441-461.

Loveman, Mara. "High-Risk Collective Action: Defending Human Rights in Chile, Uruguay, and Argentina." American Journal off Sociology 104, no. 2 (1998), 477-525. Doi: 10.1086/210045

Medina, Rocío Mateo. “De Madres de Soacha a Sujetas Políticas: Capacidad de Agenia Ante La Impunidad En Colombia: Recontrucción de Un Caso Desde Una Mirada Feministas Para Un Litigio Estratégico." ICIP Working Papers 4 (2013), 1-57.

Matveeva, Anna. "Early Warning and Early Repsonse: Conceptual and Empirical Dilemmas." Issue Paper 1. The Hague: European Centre for Conflict Prevention, 2006.

Mazurana, Dyan, Roxani Krystalli, and Anton Baaré. "Gender and Disarmament, Demobilization and Reintegration: Reviewing and Advancing theField." In The Oxford Handbook of Gender and Conflict, edited by Fionnuala Ní Aoláin, Naomi Cahn, Dina Francesca Haynes, and Valji, 442455. Oxford: Oxford University Press, 2018. Doi: 10.1093/oxfordhb/9780199300983.013.35

McEvoy, Kieran and Kirsten McConnachie. "Victims and Transitional Justice: Voice, Agency and Blame." Social \& Legal Studies 22, no. 4 (2013), 489-513. Doi: 10.1177/0964663913499062 
Meertens, Donny. “Forced Displacement and Gender Justice in Colombia Between Disproportional Effects of Violence and Historical Injustice." Case Studies on Transitional Justice and Displacement. ICTJ and Brookings-LSE, July 2012.

"Forced Displacement and Women's Security in Colombia." Disasters 34, no. 2 (2010), $147-164$.

Mertens, Charlotte and Henri Myrttinen. "'A Real Woman Waits' - Heteronormative Respectability, Neo-Liberal Betterment and Echoes of Coloniality in SGBV Programming in Eastern DR Congo." Journal of Intervention and Statebuilding (2019), 418-439. Doi: 10.1080/17502977.2019.1610992

Mhajne, Anwar and Crystal Whetstone. "The Use of Political Motherhood in Egypt's Arab Spring Uprising and Aftermath." International Feminist Journal of Politics 20, no. 1 (2018), 54-68. Doi: $10.1080 / 14616742.2017 .1371624$

Moghadam, Valentine. “Gender and Revolutions.” In Theorizing Revolutions, edited by John Foran. London: Routledge, 1997.

Molyneux, Maxine. "Mobilisation without Emancipation? Women's Interests, the State, and Revolution in Nicaragua." Feminist Studies 11, no. 2 (1985), 227-254. Doi: 10.2307/3177922

--------. "Women's Grass-Roots Organisations and Solidarity Networks: A Rediscovered Policy Resource." In Des Brèches Dans La Ville: Organisations Urbaines, Environnement et Transformation Des Rapports de Genre, edited by Christine Verschuur and François Hainard, 142-155. Bern: Graduate Institute Publications, 2016. Doi: 10.4000/books.iheid.6568

Moser, Caroline. "The Gendered Continuum of Violence and Conflict: An Operational Framework." In Victims, Perpetrators or Actors? Gender, Armed Conflict and Political Violence, edited by Caroline O.N. Moser and Fiona C. Clark, 30-51. London: Zed Books, 2001.

Moser, Caroline and Fiona Clark. "Introduction." In Victims, Perpetrators or Actors? Gender, Armed Conflict and Political Violence, edited by Caroline Moser and Fiona Clark, 3-12. London: Zed Books, 2001.

Muller, Edward and Karl-Dieter Opp. "Rational Choice and Rebellious Collective Action." American Political Science Review 80, no. 2 (1986), 471-488. Doi: 10.2307/1958269

Murdock, Donna. When Women Have Wings: Feminism and Developmnet in Medellin, Colombia. Ann Arbor: University of Michigan Press, 2008. Doi: 10.3998/mpub.286385

Mwaûra, Cirû and Susanne Schmeidl. Early Warning and Conflict Management in the Horn of Africa. Asmara, Eritrea: The Red Sea Press, Inc., 2002.

Navarro, Marysa. "The Personal Is Political: Las Madres de Plaza de Mayo." In Power and Popular Protest: Latin American Social Movements, edited by Susan Eckstein, 241-259. Berkeley: University of California Press, 1989.

Ní Aoláin, Fionnuala, Dina Francesca Haynes, and Naomi Cahn. On the Frontlines: Gender, War, and the Post-Conflict Process. Oxford: Oxford University Press, 2011.

Nordstrom, Carolyn. Girls and Warzones: Troubling Questions. Uppsala: Life and Peace Institute, 2004.

"The Tomorrow of Violence." In Violence, edited by Neil Whitehead, 223-242. Santa Fe: School of American Research Press, 2004.

Olson, Mancur. The Logic of Collective Action. Cambridge, MA: Harvard University Press, 1965.

Otto, Dianne. "Women, Peace, and Security: A Critical Analysis of the Security Council's Vision." In The Oxford Handbook of Gender and Conflict, edited by Fionnuala Ní Aoláin, Naomi Cahn, Dina Francesca Haynes, and Nahla Valji, 105-118. Oxford: Oxford University Press, 2018. Doi: 10.1093/oxfordhb/9780199300983.013.9

Paarlberg-Kvam, Kate. "What's to Come Is More Complication: Feminist Visions of Peace in Colombia." International Feminist Journal of Politics 21, no. 2 (2019), 194-223. Doi: $\underline{10.1080 / 14616742.2018 .1487266}$

Pain, Adam and Simon Levine. "A Conceptual Analysis of Livelihoods and Resilience: Addressing the 'Insecurity of Agency'." HPG Working Paper. London: Overseas Development Institute, 2012.

Parkin Daniels, Joe. "Colombian Army Killed Thousands More Civilians than Reported, Study Claims." The Guardian, May 8, 2018. Accessed November 21, 2019. https://www. theguardian.com/world/2018/may/08/colombia-false-positives-scandal-casualties-higher- 
thought-study.

Pratt, Nicola and Sophie Richter-Devroe. "Critically Examining UNSCR 1325 on Women, Peace and Security." International Feminist Journal of Politics 13, no. 4 (2011), 489-503. Doi: $\underline{10.1080 / 14616742.2011 .611658}$

Redfern, Corinne. "'Aren't Men Just Cleverer than Women?': Building a Feminist City in the Philippines." The Guardian, December 13, 2017. Accessed November 21, 2019. https:// www.theguardian.com/working-in-development/2017/dec/13/building-feminist-cityphilippines.

Restrepo, Elvira Maria. "Leaders against All Odds: Women Victims of Conflict in Colombia." Palgrave Communications 2, no. 16014 (2016). Doi: 10.1057/palcomms.2016.14

Rojas, Omar and Fabián Benavides. Ejecuciones Extrajudiiales En Colombia, 2002-2010: Obediencia Ciega En Campos de Batalla Ficticios. Bogotá: Universidad Santo Tomás, 2017. Doi: 10.2307/j. ctvckq91p.1

Ruddick, Sara. Maternal Thinking: Towards a Politics of Peace. 2nd ed. Boston: Beacon Press, 1995.

Sandvik, Kristin Bergtora. "Gendering Violent Pluralism: Women's Political Organising in Latin America." Third World Thematics: A TWQ Journal, June 13, 2018, 1-16. Doi: $\underline{10.1080 / 23802014.2018 .1477527}$

Sandvik, Kristin Bergtora and Julieta Lemaitre. "Internally Displaced Women as Knowledge Producers and Users in Humanitarian Action: The View from Colombia." Disasters 37, no. 1 (2013), 36-50.

Sjoberg, Laura. Women as Wartime Rapists: Beyond Sensation and Stereotyping. New York: New York University Press, 2016. Doi: 10.2307/j.ctt1bj4r7q

Spivak, Gayatri Chakravorty. "Can the Subaltern Speak?" In Marxism and the Interpretation of Culture, edited by Cary Nelson and Lawrence Grossberg, 271-316. Urbana: University of Illinois Press, 1988.

Starr, Lisa and Claudia Mitchell. "How Can Canada's Feminist International Assistance Policy Support a Feminist Agenda in Africa? Challenges in Addressing Sexual Violence in Four Agricultural Colleges in Ethiopia." Agenda-Empowering Women for Gender Equity 32, no. 1 (2018), 107-118. Doi:10.1080/10130950.2018.1427692

Stephen, Lynn. Women and Social Movements in Latin America: Power from Below. Austin: University of Texas Press, 1997.

Theidon, Kimberly. "1325+17=?: Filling in the Blanks of the Women, Peace and Security Agenda." In The Oxford Handbook of Gender and Conflict, edited by Fionnuala Ní Aoláin, Naomi Cahn, Dina Francesca Haynes, and Nahla Valji, 145-156. Oxford: Oxford University Press, 2018. Doi: 10.1093/oxfordhb/9780199300983.013.12

----------. "Reconstructing Masculinities: The Disarmament, Demobilization, and Reintegration of Former Combatants in Colombia." Human Rights Quarterly 31, no. 1 (2009), 1-34. Doi: 10.1353/hrq.0.0053

Thomas Davis Maya and Julia Zulver. "Colombia's City of Women." Al Jazeera, December 11, 2015. Accessed November 21, 2019. http://www.aljazeera.com/indepth/features/2015/12/ colombia-city-women-151211085034832.html.

United Nations Development Program. "From Commitment to Action: Policies to End Violence Against Women in Latin America and the Caribbean." Panama: Nuria López, 2017.

United Nations Office of the High Commissioner for Human Rights. Informe Anual Del Alto Comisionado de Las Naciones Unidas Para Los Derechos Humanos Sobre La Situación de Los Derechos Humanos En Colombia. March 21, 2018. UN Doc. A/HRC/34/3.

United Nations Security Council. Resolution 1366. August 31, 2001. UN Doc. S/RES/1366.

Viterna, Jocelyn. "Pulled, Pushed, and Persuaded: Explaining Women's Mobilization into the Salvadoran Guerrilla Army." American Journal of Sociology 112, no. 1 (2006), 1-45. Doi: $\underline{10.1086 / 502690}$

-------. Women in War: The Micro-Processes of Mobilization in El Salvador. London: Oxford University Press, 2013.

Zulver, Julia. "Asociación de Mujeres Afro Por La Paz (AFROMUPAZ): Differential Feminism in 
Cuerpo y Cara de Mujer." Latin American Perspectives, forthcoming.

. "Building the City of Women: Creating a Site of Feminist Resistance in a Conflict Zone." Gender, Place, and Culture 24, no. 10 (2017), 1498-1516. Doi: 10.1080/0966369x.2017.1387105

. “Colectiva Matamba: The Afro-Colombian Women's Collective Mobilizing Against Structural Racism." NACLA 50, no. 4 (2018), 377-380. Doi: 10.1080/10714839.2018.1550980 . "Feasible Justice? How to Guarantee Reparations for Colombia's 8.3 Million Victims." JusticeInfo.Net, 2018. Accessed November 21, 2019. https://www.justiceinfo.net/en/justicereconciliation/37686-feasible-justice-has-colombia-over-promised-and-under-deliveredreparations-for-its-8-6-million-vic.html.

."High-Risk Feminism in El Salvador: Women's Mobilisation in Violent Times." Gender and Development 24, no. 2 (2016), 171-185. Doi: 10.1080/13552074.2016.1200883

. "High Risk Feminism in Colombia: Women's Mobilisation in Violent Contexts." PhD diss., University of Oxford, 2018. Accessed November 21, 2019. https://ora.ox.ac.uk/objects/ uuid:3fc50c53-d6f5-49c9-a3ba-ca68570a78a3.

---------. "Women Weaving Life in Southern Colombia." NACLA, 2019. Accessed November 21, 2019. https://nacla.org/news/2019/04/11/women-weaving-life-southern-colombia. 